Prepared in cooperation with the Mississippi Department of Transportation

\title{
Magnitude and Frequency of Floods in the Alluvial Plain of the Lower Mississippi River, 2017
}

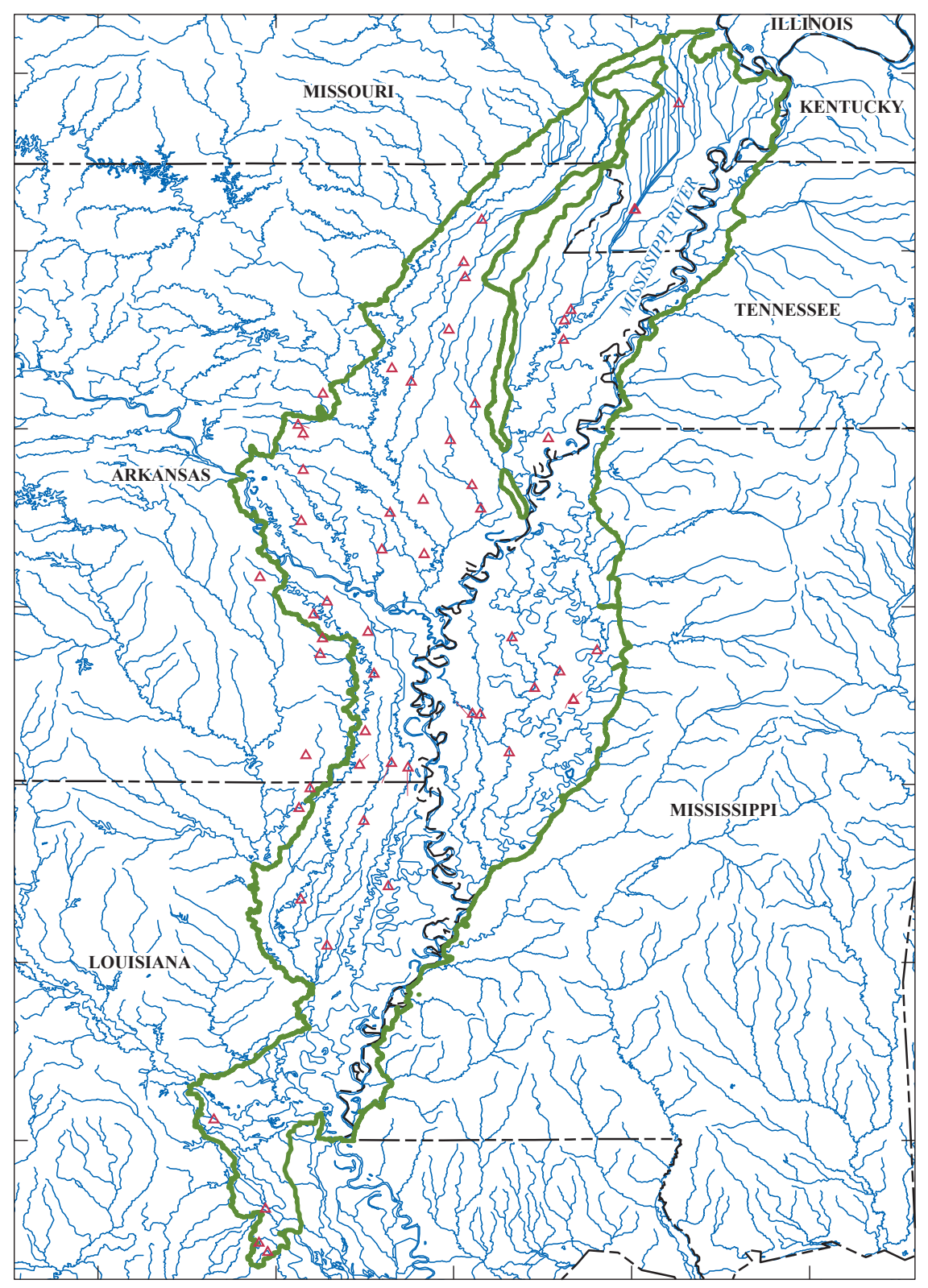

Scientific Investigations Report 2021-5046 



\section{Magnitude and Frequency of Floods in the Alluvial Plain of the Lower Mississippi River, 2017}

By Brandon T. Anderson

Prepared in cooperation with the Mississippi Department of Transportation

Scientific Investigations Report 2021-5046 
For more information on the USGS - the Federal source for science about the Earth, its natural and living resources, natural hazards, and the environment-visit https://www.usgs.gov or call 1-888-ASK-USGS.

For an overview of USGS information products, including maps, imagery, and publications, visit https://store.usgs.gov/.

Any use of trade, firm, or product names is for descriptive purposes only and does not imply endorsement by the U.S. Government.

Although this information product, for the most part, is in the public domain, it also may contain copyrighted materials as noted in the text. Permission to reproduce copyrighted items must be secured from the copyright owner.

Suggested citation:

Anderson, B.T., 2021, Magnitude and frequency of floods in the alluvial plain of the lower Mississippi River, 2017: U.S. Geological Survey Scientific Investigations Report 2021-5046, 15 p., https://doi.org/10.3133/sir20215046.

ISSN 2328-031X (print) ISSN 2328-0328 (online) 


\section{Contents}

Abstract

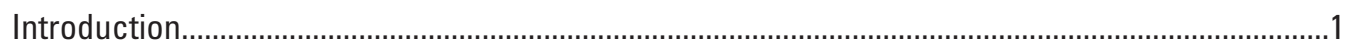

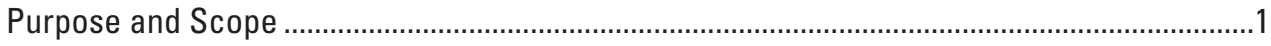

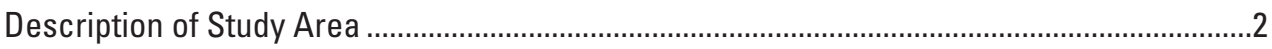

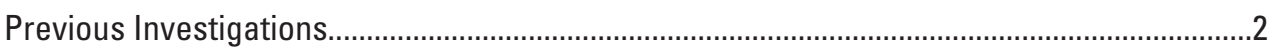

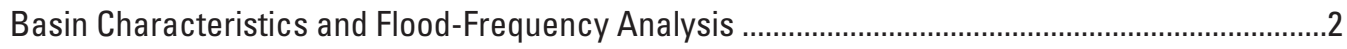

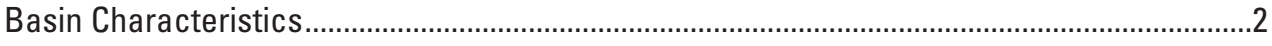

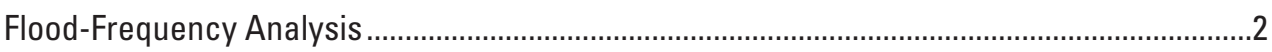

Regression Analysis .............................................................................................................

Application of Regression Equations for Estimating Annual Exceedance

Probability Streamflows in the Mississippi Alluvial Plain .....................................

Estimating Annual Exceedance Probability Flows ……................................................................

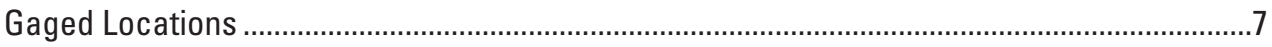

Ungaged Locations on Gaged Streams ..................................................................................

Locations on Ungaged Streams ...................................................................................

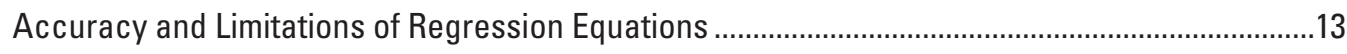

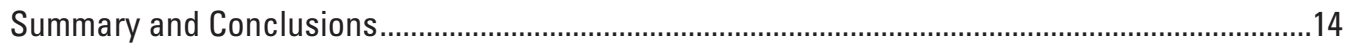

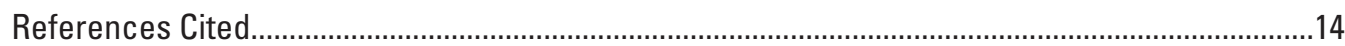

\section{Figures}

1. Map showing locations of streamgages used in regional regression analysis in the alluvial plain of the lower Mississippi River.....

\section{Tables}

1. Information and selected basin characteristics for U.S. Geological Survey streamgages in Mississippi, Arkansas, Missouri, and Louisiana that were used in the regional regression analysis.

2. Final regional regression equations for estimating annual exceedance probability flows for rural streams in the alluvial plain of the lower Mississippi River and generalized least-squares regression model diagnostics.

3. Annual exceedance probability flows for 58 U.S. Geological Survey streamgages used in regional regression analysis based on data through the 2017 water year 


\section{Conversion Factors}

U.S. customary units to International System of Units

\begin{tabular}{|c|c|c|}
\hline Multiply & By & To obtain \\
\hline \multicolumn{3}{|c|}{ Length } \\
\hline inch (in.) & 2.54 & centimeter $(\mathrm{cm})$ \\
\hline inch (in.) & 25.4 & millimeter $(\mathrm{mm})$ \\
\hline \multicolumn{3}{|c|}{ Area } \\
\hline square mile $\left(\mathrm{mi}^{2}\right)$ & 259.0 & hectare (ha) \\
\hline square mile $\left(\mathrm{mi}^{2}\right)$ & 2.590 & square kilometer $\left(\mathrm{km}^{2}\right)$ \\
\hline \multicolumn{3}{|c|}{ Flow rate } \\
\hline cubic foot per second $\left(\mathrm{ft}^{3} / \mathrm{s}\right)$ & 0.02832 & cubic meter per second $\left(\mathrm{m}^{3} / \mathrm{s}\right)$ \\
\hline \multicolumn{3}{|c|}{ Hydraulic gradient } \\
\hline foot per mile (ft/mi) & 0.1894 & meter per kilometer $(\mathrm{m} / \mathrm{km})$ \\
\hline
\end{tabular}

Temperature in degrees Fahrenheit $\left({ }^{\circ} \mathrm{F}\right)$ may be converted to degrees Celsius $\left({ }^{\circ} \mathrm{C}\right)$ as follows:

${ }^{\circ} \mathrm{C}=\left({ }^{\circ} \mathrm{F}-32\right) / 1.8$.

\section{Datum}

Horizontal coordinate information is referenced to the North American Datum of 1983 (NAD 83).

\section{Abbreviations}

AEP annual exceedance probability

EMA Expected Moments Algorithm

GIS geographic information system

GLS generalized least squares

LP3 log-Pearson type III

MAP Mississippi Alluvial Plain

MGB multiple Grubbs-Beck test

MSE mean square error

NWIS National Water Information System

OLS ordinary least squares

PILFs potentially influential low floods

SEP standard error of prediction

USGS U.S. Geological Survey

WREG weighted-multiple-linear regression program 


\title{
Magnitude and Frequency of Floods in the Alluvial Plain of the Lower Mississippi River, 2017
}

\author{
By Brandon T. Anderson
}

\section{Abstract}

Annual exceedance probability flows at gaged locations and regional regression equations used to estimate annual exceedance probability flows at ungaged locations were developed by the U.S. Geological Survey, in cooperation with the Mississippi Department of Transportation, to improve floodfrequency estimates at rural streams in the alluvial plain of the lower Mississippi River. These estimates were developed using current geospatial data, analytical methods, and annual peak-flow data through September 2017 at 58 streamgages in the alluvial plain of the lower Mississippi River, including 9 in Mississippi, 35 in Arkansas, 4 in Missouri, and 10 in Louisiana. Annual exceedance probability flows presented in this report incorporate streamflow data through the 2017 water year, 32 additional years of record since the previous study in 1985 of flood magnitude and frequency in the Mississippi portion of the alluvial plain of the lower Mississippi River. Ranges for standard error of prediction, average variance of prediction, and pseudo- $\mathrm{R}^{2}$ are 45-61 percent, 0.035-0.059 (log cubic feet per second $)^{2}$, and 90-94 percent, respectively.

\section{Introduction}

Improved flood-frequency information is important for the effective management of flood plains, including the safe and economic design of bridges, culverts, dams, levees, and other structures near streams. The last flood-frequency study of the Mississippi Alluvial Plain (MAP) was published more than 35 years ago for the streamgages located in Mississippi (Landers, 1985). Since that time, improvements in statistical techniques, specifically the Expected Moments Algorithm (EMA) and the multiple Grubbs-Beck (MGB) test for potentially influential low floods, have increased the accuracy of flood-frequency estimates (Cohn and others, 1997, 2013). The EMA allows for the incorporation of censored observations, historical flood data, low outliers, and uncertain data points in the flood-frequency analysis. The MGB test is recommended for use with the EMA as it increases the accuracy of peak-flow statistics by objectively and systematically detecting and removing low, highly influential peak flows.
The unique topography and hydrology of the MAP region - characterized by broad, widely meandering stream courses with low channel slopes, abundant channel and overbank storage in abandoned meander belts, oxbow lakes, swamps, and extensive hydrologic alteration of natural stream courses by channelization and levees - make the region highly susceptible to flood damage because floodwaters cover a larger area for a greater length of time for a given flood magnitude than in surrounding regions. The distinct topography and hydrology of the MAP warrant a unique flood-frequency analysis for the region.

In 2019, the U.S. Geological Survey (USGS), in cooperation with the Mississippi Department of Transportation, began a study to update annual exceedance probability (AEP) flows for selected streamgages in the MAP and regression equations for estimating AEP flows at ungaged locations in the region using recent geospatial data, current analytical methods, and additional annual peak-flow data through the 2017 water year. ${ }^{1}$ The AEP flows and regression equations will be incorporated into the USGS StreamStats application, an online tool that provides flood-response planners and water managers with the ability to delineate the drainage basin at a selected location on a stream, generate basin characteristics, and estimate flow statistics (U.S. Geological Survey, 2017a).

\section{Purpose and Scope}

The purpose of this report is to document updates to (1) AEP flows, using annual peak-flow data through the 2017 water year, for 58 selected streamgages in the MAP in Mississippi, Missouri, Arkansas, and Louisiana; and (2) regression equations used to estimate AEP flows at ungaged locations on streams in the MAP. Peak-flow data used in support of the analysis were downloaded from the USGS National Water Information System (NWIS) database (U.S. Geological Survey, 2017b); geographic information system (GIS)-generated basin characteristics for the MAP were generated using the USGS StreamStats application (U.S. Geological Survey, 2017a; https://streamstats.usgs.gov/ss/). Six gages

\footnotetext{
${ }^{1}$ The water year is the annual period from October 1 through September 30 and is designated by the year in which the period ends. For example, the 2013 water year is from October 1, 2012, through September 30, 2013.
} 
from outside the boundary of the study area were included in the study because these gages possess characteristics consistent with those in the study area.

\section{Description of Study Area}

The study area (fig. 1) includes the MAP with selected streamgages in Mississippi, Arkansas, Missouri, and Louisiana. Rainfall in the MAP generally is associated with the movement of warm and cold fronts across the States from November through April and isolated thunderstorms from May through October. From June through September, tropical storms or hurricanes occasionally enter the States along the Gulf Coast and produce unusually large amounts of rainfall. The average annual precipitation for the MAP is 51.77 inches (U.S. Climate Data, 2020). The average annual high and low temperatures are 75 and 52 degrees Fahrenheit, respectively (U.S. Climate Data, 2020). The topography of the MAP region is characterized by broad, widely meandering stream courses with low channel slopes, large amounts of channel and overbank storage in abandoned meander belts, oxbow lakes, swamps, and extensive alteration of natural channel courses by channelization and levees.

\section{Previous Investigations}

Wilson and Trotter (1961) developed techniques for estimating the magnitude and frequency of floods for streams in Mississippi. Colson and Hudson (1976) used a multiplelinear regression model to update those techniques. Wilson and Trotter (1961) and Colson and Hudson (1976) updated the flood frequency for the entire State of Mississippi, including the MAP. Landers (1985) used linear regressions to develop updated techniques for estimating the magnitude and frequency of floods for streams in the alluvial plain of the lower Mississippi River. In the report, Landers also expressed the need for a separate flood frequency analysis for the MAP. Recent publications for subsections of the MAP region are Southard and Veilleux (2014) and Wagner and others (2016). These two reports also contain updated Bayesian generalized least-squares (GLS) regional skew values for the subsections of the MAP represented.

\section{Basin Characteristics and Flood-Frequency Analysis}

\section{Basin Characteristics}

Basin characteristics for the streamgages used in this study were obtained from the USGS map-based web application StreamStats (U.S. Geological Survey, 2017a). The following basin characteristics were tested for statistical significance in the GLS regression analysis:
- Contributing drainage area $(A)$, in square miles, upstream from the streamgage.

- Main channel slope $(S)$, in feet per mile, between points 10 and 85 percent of the distance from the streamgage to the basin divide.

- Main channel length $(L)$, in miles, between the streamgage and the basin divide.

- Lag-time factor $(T)$, defined by the ratio $L / S^{0.5}$, with $L$ and $S$ defined above.

- Storage $(S t)$, in percent, defined as the percentage of the total contributing drainage area covered by lakes, ponds, and swamps.

- Basin shape ratio $\left(L^{2} / A\right)$, of the longest flow path length to drainage area. The length of the longest flow path $(L)$ is squared and divided by the drainage area for the basin $(A)$. This ratio is essentially a basin shape factor with $L$ and $A$ defined above.

Initial GLS regression analyses were performed for all streamgages included in the study (table 1) and incorporated multiple combinations of the aforementioned explanatory variables. The combination of drainage area, slope, and basin shape yielded the lowest standard errors of prediction and therefore were used to estimate AEPs at ungaged locations in the MAP. The drainage areas of the 58 streamgages range from 0.03 to 2,370 square miles $\left(\mathrm{mi}^{2}\right)$, slopes range from 0.36 to 31.74 feet per mile, and basin shape ratios range from 1.24 to 75.97 .

The quality of GIS-derived basin characteristics for the MAP is a condition of the low channel slopes, large amounts of channel and overbank storage, and extensive hydraulic alteration characteristic of stream courses in the region. Because of these factors, GIS-derived basin characteristics require extra quality assurance to ensure that they are accurate. Special care should be taken with locations having drainage areas less than $1 \mathrm{mi}^{2}$; the basin boundaries might require editing in StreamStats to yield the correct basin polygons, and therefore characteristics, for the desired locations.

\section{Flood-Frequency Analysis}

Fifty-eight streamgages operated by the USGS in the MAP - 9 in Mississippi, 35 in Arkansas, 4 in Missouri, and 10 in Louisiana - that had 10 or more years of annual peakflow data through the 2017 water year were considered for use in the regression analysis. The streamgages were either continuous-record or crest-stage gages. Continuous-record gages are equipped with instrumentation that records the height of the water surface above the gage datum, or stage, of the water body at fixed time intervals. The stage data are transmitted by satellite to USGS offices where flow from stagestreamflow rating is applied to each stage value. Crest-stage gages record only the peak stages of floods; flow from a stagestreamflow rating is then applied to the peak stage for the year. 


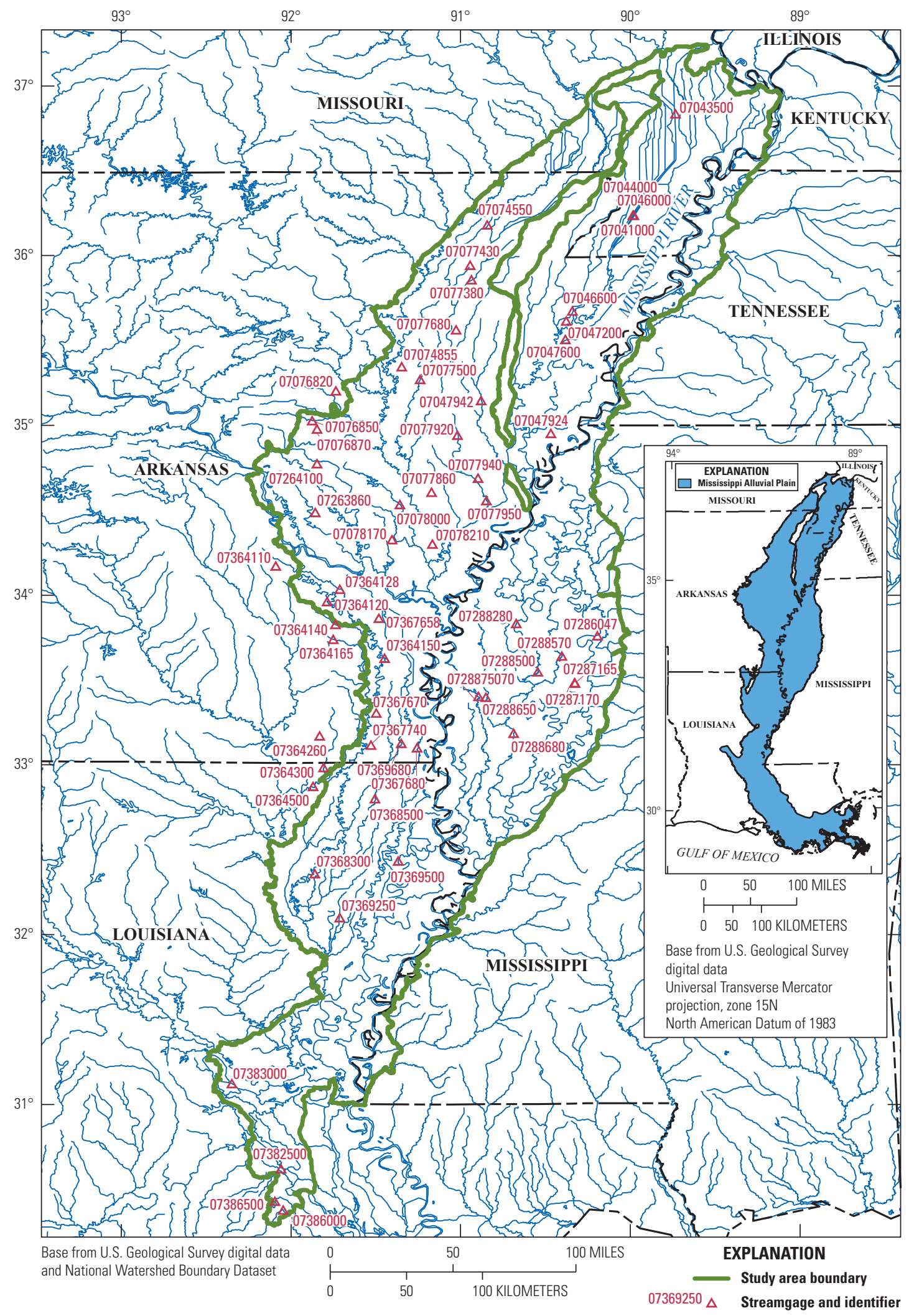

Figure 1. Locations of streamgages used in regional regression analysis in the alluvial plain of the lower Mississippi River. 
Table 1. Information and selected basin characteristics for U.S. Geological Survey streamgages in Mississippi, Arkansas, Missouri, and Louisiana that were used in the regional regression analysis.

[Data in this table are available from the U.S. Geological Survey National Water Information System database (https://waterdata.usgs.gov/nwis) and StreamStats (https://streamstats.usgs.gov/ss/). Dates shown as month, day, and year or as month and year if exact date is not known. Horizontal coordinate information is referenced to the North American Datum of 1983. USGS, U.S. Geological Survey; GIS, geographic information system; $\mathrm{mi}^{2}$, square mile; ft/mi, foot per mile]

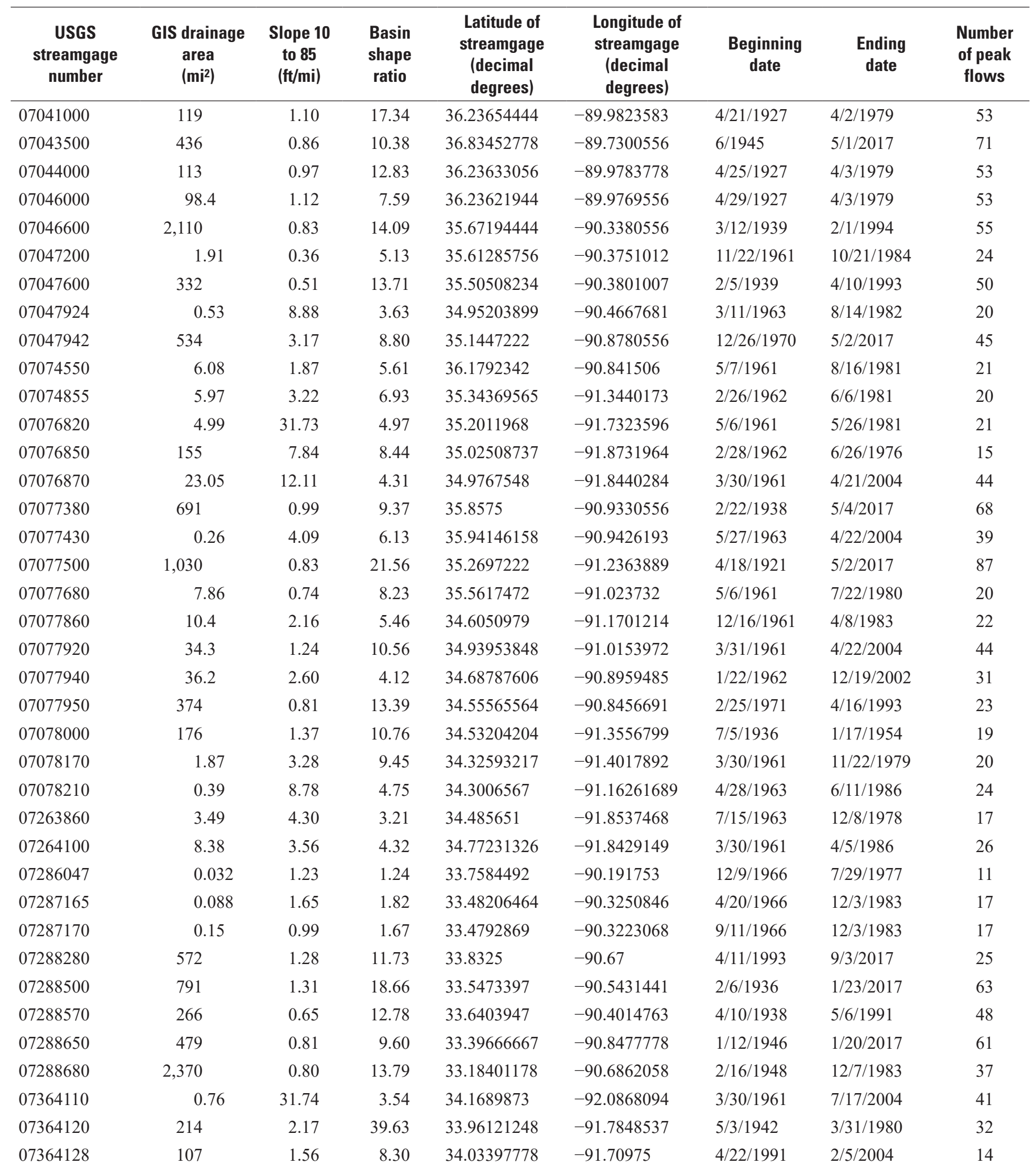


Table 1. Information and selected basin characteristics for U.S. Geological Survey streamgages in Mississippi, Arkansas, Missouri, and Louisiana that were used in the regional regression analysis. - Continued

[Data in this table are available from the U.S. Geological Survey National Water Information System database (https://waterdata.usgs.gov/nwis) and StreamStats (https://streamstats.usgs.gov/ss/). Dates shown as month, day, and year or as month and year if exact date is not known. Horizontal coordinate information is referenced to the North American Datum of 1983. USGS, U.S. Geological Survey; GIS, geographic information system; $\mathrm{mi}^{2}$, square mile; ft/mi, foot per mile]

\begin{tabular}{lcccccccc}
\hline $\begin{array}{c}\text { USGS } \\
\text { streamgage } \\
\text { number }\end{array}$ & $\begin{array}{c}\text { GIS drainage } \\
\text { area } \\
\text { (mi2) }\end{array}$ & $\begin{array}{c}\text { Slope 10 } \\
\text { to 85 } \\
\text { (ft/mi) }\end{array}$ & $\begin{array}{c}\text { Basin } \\
\text { shape } \\
\text { ratio }\end{array}$ & $\begin{array}{c}\text { Latitude of } \\
\text { streamgage } \\
\text { (decimal } \\
\text { degrees) }\end{array}$ & $\begin{array}{c}\text { Longitude of } \\
\text { streamgage } \\
\text { (decimal } \\
\text { degrees) }\end{array}$ & $\begin{array}{c}\text { Beginning } \\
\text { date }\end{array}$ & $\begin{array}{c}\text { Ending } \\
\text { date }\end{array}$ & $\begin{array}{c}\text { Number } \\
\text { of peak } \\
\text { flows }\end{array}$ \\
\hline 07364140 & 36 & 16.45 & 4.50 & 33.82482634 & -91.7351298 & $4 / 8 / 1993$ & $3 / 1 / 2004$ & 11 \\
07364150 & 608 & 1.29 & 60.00 & 33.62777778 & -91.4458333 & $4 / 13 / 1905$ & $6 / 11 / 2017$ & 81 \\
07364165 & 18.2 & 12.75 & 4.07 & 33.73899468 & -91.7476299 & $5 / 27 / 1963$ & $12 / 28 / 1982$ & 21 \\
07364260 & 21.1 & 6.63 & 5.25 & 33.17012176 & -91.8279064 & $12 / 16 / 1961$ & $12 / 27 / 1982$ & 22 \\
07364300 & 274 & 2.91 & 8.47 & 32.9820721 & -91.8056818 & $4 / 7 / 1956$ & $1 / 22 / 2017$ & 27 \\
07364500 & 1,622 & 0.84 & 75.97 & 32.87235338 & -91.8679054 & $4 / 1 / 1927$ & $4 / 16 / 1980$ & 53 \\
07367658 & 1.31 & 4.60 & 3.87 & 33.86315944 & -91.4795674 & $3 / 30 / 1961$ & $7 / 2 / 1986$ & 26 \\
07367670 & 2.44 & 1.99 & 3.12 & 33.3042843 & -91.4937318 & $2 / 20 / 1961$ & $12 / 27 / 1982$ & 23 \\
07367680 & 571 & 0.80 & 26.60 & 33.12416667 & -91.3477778 & $3 / 31 / 1939$ & $3 / 11 / 2016$ & 57 \\
07367740 & 2.20 & 3.22 & 4.44 & 33.11540059 & -91.5253976 & $5 / 27 / 1963$ & $10 / 7 / 1984$ & 23 \\
07368300 & 0.15 & 3.51 & 8.51 & 32.35709119 & -91.8570728 & $2 / 10 / 1966$ & $2 / 1 / 1981$ & 16 \\
07368500 & 36.9 & 0.92 & 8.85 & 32.798743 & -91.5015072 & $12 / 9 / 1940$ & $3 / 5 / 1977$ & 37 \\
07369250 & 0.40 & 4.53 & 3.32 & 32.09876548 & -91.7084587 & $5 / 23 / 1955$ & $5 / 1 / 1967$ & 13 \\
07369500 & 309 & 1.10 & 6.38 & 32.43208704 & -91.36678139 & $5 / 15 / 1927$ & $4 / 3 / 2017$ & 84 \\
07369680 & 528 & 1.06 & 18.93 & 33.10027778 & -91.2544444 & $12 / 1931$ & $8 / 9 / 2017$ & 80 \\
07382500 & 715 & 1.00 & 7.45 & 30.61825175 & -92.0556741 & $8 / 12 / 1940$ & $5 / 8 / 2017$ & 72 \\
07383000 & 78.9 & 1.16 & 5.12 & 31.1196322 & -92.3445769 & $4 / 19 / 1943$ & $6 / 3 / 1905$ & 37 \\
07386000 & 37.1 & 2.20 & 3.14 & 30.37658758 & -92.0431756 & $8 / 1940$ & $3 / 2 / 1964$ & 21 \\
07386500 & 19.0 & 1.80 & 6.72 & 30.42797613 & -92.0917879 & $3 / 25 / 1943$ & $5 / 16 / 1970$ & 28 \\
0728875070 & 79.9 & 0.51 & 28.24 & 33.4011111 & -90.8919444 & $12 / 17 / 2001$ & $7 / 22 / 2014$ & 13 \\
\hline
\end{tabular}

Annual peak-flow data for the streamgages were downloaded from the USGS National Water Information System (NWIS) database (U.S. Geological Survey, 2017b). Annual peak-flow records were evaluated for extensive regulation, diversion, and urbanization by inspecting NWIS peakflow qualification codes. Annual peaks affected by extensive regulation or diversion were not considered for use in the study and removed from the dataset. Streamgages having basins with more than 10 percent of the drainage area covered by an impervious surface were considered urbanized and were not included in this study. Annual peak flows for the 58 streamgages were analyzed using version 7.3 of USGS peak-flow analysis software PeakFQ (U.S. Geological Survey, 2014).

Following the guidelines set forth in Bulletin 17C (England and others, 2019), a log-Pearson type III (LP3) mathematical probability distribution was fit to the annual peak-flow data from each streamgage and then used to estimate streamflow values corresponding to a range of annual exceedance probabilities $(0.5,0.2,0.1,0.04,0.02$, $0.01,0.005,0.002)$. The LP3 is a three-parameter distribution that requires estimates of the mean, standard deviation, and skew coefficient (that is, the "moments") of the population of base 10 logarithms of annual peak flows at each streamgage (Parrett and others, 2011). EMA improves upon the standard LP3 method by allowing for the incorporation of "flood knowledge," historic data and peaks, censored observations, and uncertain data points by using perception thresholds and flow intervals to represent such data (Cohn and others, 1997). In an EMA analysis, perception thresholds are used to describe such "flood knowledge" in each year within the annual peakflow record and represent the observable range in floods (England and others, 2019). If no historic, censored, or interval 
data are incorporated, the EMA method produces estimates of the three LP3 moments that are identical to those produced by the standard LP3 method described in Bulletin 17B (Interagency Advisory Committee on Water Data, 1982). For streamgages in the part of the MAP in Arkansas, Louisiana, and Missouri, regional skew had been updated within the past 10 years (Southard and Veilleux, 2014; Wagner and others, 2016), and that regional skew value and corresponding MSE $(-0.17$ and 0.121 , respectively) were used to weight the station skew. For streamgages in the part of the MAP in Mississippi, skew values were not available from Bulletin 17C; therefore, generalized skew (\#) and the corresponding mean square error (MSE) values (\#) from Bulletin 17B were used to weight the station skew.

The basic equation for fitting the LP3 distribution to a measured series of annual peak flows is

$$
\log Q_{p}=\overline{\mathrm{X}}+K_{p} S
$$

where
$Q_{p} \quad$ is the $P$-percent AEP flow, in cubic feet per second;
$\overline{\mathrm{X}} \quad$ is the mean of the logarithms of the annual peak flows;
$K_{p} \quad$ is a factor based on the skew coefficient and the given percentage of annual exceedance probability, which can be obtained from appendix 3 of Bulletin 17B (Interagency Advisory Committee on Water Data, 1982); and
$S \quad$ is the standard deviation of the logarithms of the annual peak flows.

The term "recurrence interval, in years" is commonly used to characterize flood frequency (for example, a "50-year flood"); however, the USGS and other Federal agencies now refer to the $P$-percent chance of occurrence (AEP). For example, the $0.02 \mathrm{AEP}\left(\mathrm{Q}_{2 \text { percent }}\right)$ has a 2-percent chance of occurring in any given year and corresponds to a recurrence interval of 50 years (reciprocal of the AEP; Griffis and Stedinger, 2007).

The MGB test, a generalization of the Grubbs-Beck method, provides a standard procedure for identifying multiple low outliers referred to as potentially influential low floods (PILFs; Cohn and others, 2013). PILFs are annual peaks that meet three criteria: (1) their magnitude is much smaller than the flood quantile of interest; (2) they occur below a statistically significant break in the flood-frequency plot; and (3) they can have excessive influence on the estimated frequency of large floods. PILFs were excluded from the AEP flow computations for the streamgages used in the study.

\section{Regression Analysis}

AEP estimates obtained from flood-frequency analysis of annual peak-flow data from the 58 selected USGS streamgages were related to basin characteristics using ordinary least-squares multiple linear regression to evaluate the statistical significance of each basin characteristic (Wagner and others, 2016). The USGS weighted-multiplelinear regression program (WREG) version 1.05 was then used to complete the final GLS regression analysis (Eng and others, 2009; U.S. Geological Survey, 2013). In GLS regression, streamgages are weighted according to differences in streamflow record length, the variance of streamflow measurements in the record, and spatial cross-correlation of concurrent flows among streamgages.

Performance metrics for the GLS regression were reviewed. Standard error of prediction of the GLS models ranged from 45 to 61 percent (table 2). Pseudo coefficients of determination (pseudo- $\mathrm{R}^{2}$ ) of the models ranged from 90 to 94 percent. Standard model error ranged from 43 to 57 percent. Streamgages that had high leverage or influence on the regression model were identified. The leverage metric is used to compare the values of independent variables at one streamgage to the values of the same variables at all other streamgages, whereas influence is used to determine if a streamgage had a high influence on the estimated regression values (Eng and others, 2009). A streamgage may exhibit high leverage because its independent variables differ substantially from those of other streamgages in the dataset, but the same streamgage may not exhibit high influence on the regression model. Conversely, a streamgage that exhibits high influence may not exhibit high leverage. Sometimes high leverage or influence is indicative of incorrect values for one or more independent variables. One streamgage (07287505) was removed because of high influence on model performance metrics.

\section{Application of Regression Equations for Estimating Annual Exceedance Probability Streamflows in the Mississippi Alluvial Plain}

When applying the regression equations, users are advised not to interpret the empirical results as exact. Regression equations are statistical models that must be interpreted and applied within the limits of the data used to generate the models and with the understanding that the results are best-fit estimates that have an associated variance. Methods for estimating AEP flows in the MAP differ between gaged locations, ungaged locations on gaged streams, and locations on ungaged streams.

\section{Estimating Annual Exceedance Probability Flows}

Annual exceedance probability flow estimations are considered for gaged locations, ungaged locations on gaged streams, and locations on ungaged streams. 
Table 2. Final regional regression equations for estimating annual exceedance probability flows for rural streams in the alluvial plain of the lower Mississippi River and generalized least-squares regression model diagnostics.

[Delta flood region -58 streamgages. MSE, mean square error; $\mathrm{ft}^{3} / \mathrm{s}$, cubic foot per second; AVP, average variance of prediction; SEP, standard error of prediction; pseudo- $\mathrm{R}^{2}$, pseudo coefficient of determination; $\mathrm{Q}_{\# \# \%}$, annual exceedance probability flow; $\mathrm{A}$, contributing drainage area, in square miles; $\mathrm{S}$, slope from StreamStats, in feet per mile; B, basin shape ratio, $\left.\mathrm{L}^{2} / \mathrm{A}\right]$

\begin{tabular}{lcccc}
\hline $\begin{array}{c}\text { Annual exceedance probability } \\
\text { flow equation }\end{array}$ & $\begin{array}{c}\text { MSE } \\
(\operatorname{log~tt} / \mathbf{s})\end{array}$ & $\begin{array}{c}\text { AVP } \\
(\operatorname{log~ft} / \mathbf{s})^{2}\end{array}$ & $\begin{array}{c}\text { SEP } \\
\text { (percent) }\end{array}$ & $\begin{array}{c}\text { Pseudo-R } \\
\text { (percent) }\end{array}$ \\
\hline $\mathrm{Q}_{50 \%}=207(\mathrm{~A})^{0.676}(\mathrm{~S})^{0.159}(\mathrm{~B})^{-0.390}$ & 0.034 & 0.035 & 45 & 94 \\
$\mathrm{Q}_{20 \%}=259(\mathrm{~A})^{0.683}(\mathrm{~S})^{0.272}(\mathrm{~B})^{-0.374}$ & 0.034 & 0.035 & 45 & 94 \\
$\mathrm{Q}_{10 \%}=290(\mathrm{~A})^{0.684}(\mathrm{~S})^{0.328}(\mathrm{~B})^{-0.362}$ & 0.037 & 0.037 & 46 & 94 \\
$\mathrm{Q}_{4 \%}=328(\mathrm{~A})^{0.684}(\mathrm{~S})^{0.387}(\mathrm{~B})^{-0.348}$ & 0.042 & 0.041 & 50 & 93 \\
$\mathrm{Q}_{2 \%}=354(\mathrm{~A})^{0.684}(\mathrm{~S})^{0.423}(\mathrm{~B})^{-0.336}$ & 0.046 & 0.045 & 52 & 93 \\
$\mathrm{Q}_{1 \%}=378(\mathrm{~A})^{0.683}(\mathrm{~S})^{0.455}(\mathrm{~B})^{-0.326}$ & 0.050 & 0.049 & 55 & 92 \\
$\mathrm{Q}_{0.5 \%}=403(\mathrm{~A})^{0.682}(\mathrm{~S})^{0.485}(\mathrm{~B})^{-0.319}$ & 0.055 & 0.053 & 57 & 91 \\
$\mathrm{Q}_{0.2 \%}=436(\mathrm{~A})^{0.682}(\mathrm{~S})^{0.520}(\mathrm{~B})^{-0.312}$ & 0.061 & 0.059 & 61 & 90 \\
\hline
\end{tabular}

\section{Gaged Locations}

The accuracy of AEP flows at streamgages, determined using EMA, can be further improved by weighting with flows predicted using the regression equations. If AEP flows estimated using EMA and the regression equations are assumed to be independent and are weighted in inverse proportion to the associated variances, the variance of the weighted estimate will be less than the variance of either of the independent estimates. Once the variances have been computed, the two independent flow estimates can be weighted by using the following equation:

$$
\begin{gathered}
\log _{10} Q_{P(g) w}= \\
\frac{V_{p, P(g) r} * \log _{10} Q_{P(g) s}+V_{p, P(g) s} * \log _{10} Q_{P(g) r},}{V_{p, P(g) s}+V_{p, P(g) r}}
\end{gathered}
$$

where

$$
\begin{array}{cc}
Q_{P(g) w} & \begin{array}{c}
\text { is the weighted flow estimate for the selected } \\
\text { AEP, in cubic feet per second; } \\
\text { is the variance of prediction corresponding } \\
\text { to the regression equation for the selected } \\
\text { AEP, in log units; }
\end{array} \\
V_{p(g) \text { (g) } r} \quad \begin{array}{l}
\text { is the flow estimate, determined using } \\
\text { EMA, for the selected AEP, in cubic feet } \\
\text { per second; }
\end{array} \\
\begin{array}{l}
\text { is the variance of prediction from EMA for } \\
\text { the selected AEP, in log units; and }
\end{array} \\
\begin{array}{l}
\text { is the flow estimate, determined using the } \\
\text { regression equation for the selected AEP, } \\
\text { in cubic feet per second. }
\end{array}
\end{array}
$$

For all streamgages used in the study, the AEP flow estimates determined using EMA were weighted with the AEP flow estimates determined using the regression equations to compute a final set of weighted AEP flows (table 3).

\section{Ungaged Locations on Gaged Streams}

AEP flows for a streamgage can be transferred to an ungaged location on the same stream by using the area-weighting method (eq. 3). If the drainage area at an ungaged location is within 50 percent of the drainage area at a streamgage (drainage area ratio is more than 0.5 or less than 1.5) (Ries and Dillow, 2006), the drainage area ratio can be calculated as

$$
Q_{P(u)}=\left(\frac{A_{(u)}}{A_{(g)}}\right)^{b} Q_{P(g) w},
$$

where

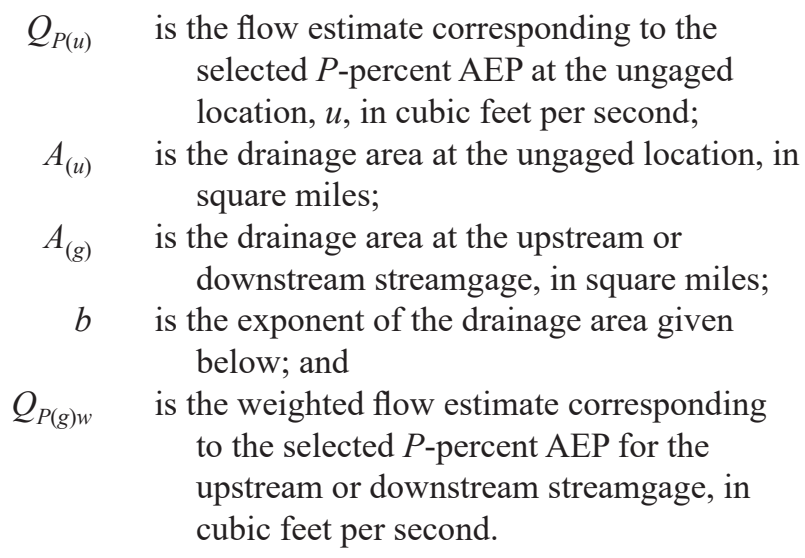


Table 3. Annual exceedance probability flows for 58 U.S. Geological Survey streamgages used in regional regression analysis based on data through the 2017 water year.

[Flows are in cubic feet per second. USGS, U.S. Geological Survey; \%, percent; Miss., Mississippi; Mo., Missouri; La., Louisiana; Ark., Arkansas; no., number; trib., tributary; St., State; Hw, highway; nr, near; Rs, research; Pd, pond; Byu, Bayou; COE, U.S. Army Corps of Engineers; EMA, Expected Moments Algorithm; RRE, regional regression equation; weighted, weighted estimate computed using equation 2; @, at; \%, percent]

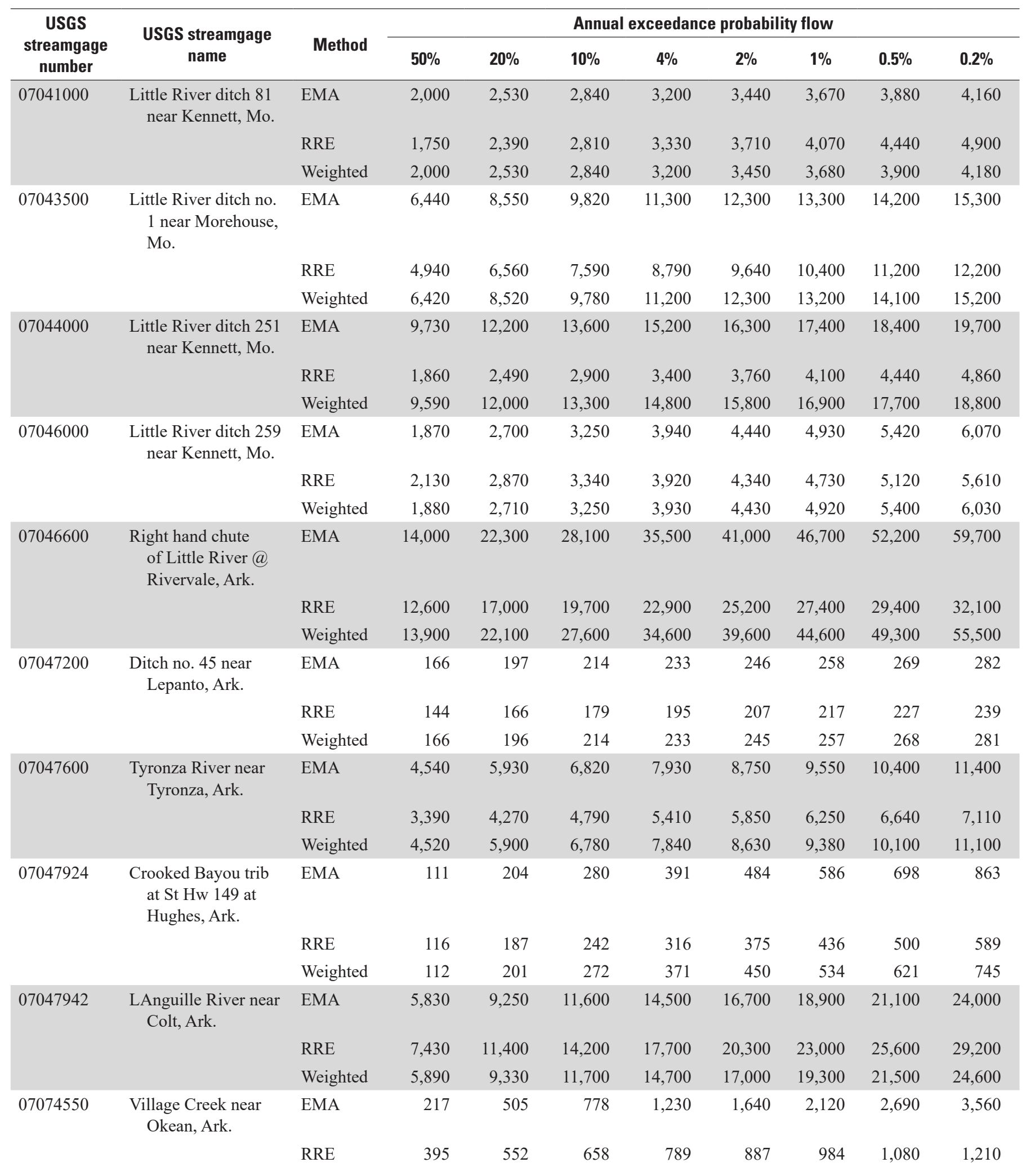


Table 3. Annual exceedance probability flows for 58 U.S. Geological Survey streamgages used in regional regression analysis based on data through the 2017 water year.-Continued

[Flows are in cubic feet per second. USGS, U.S. Geological Survey; \%, percent; Miss., Mississippi; Mo., Missouri; La., Louisiana; Ark., Arkansas; no., number; trib., tributary; St., State; Hw, highway; nr, near; Rs, research; Pd, pond; Byu, Bayou; COE, U.S. Army Corps of Engineers; EMA, Expected Moments Algorithm; RRE, regional regression equation; weighted, weighted estimate computed using equation 2; @, at; \%, percent]

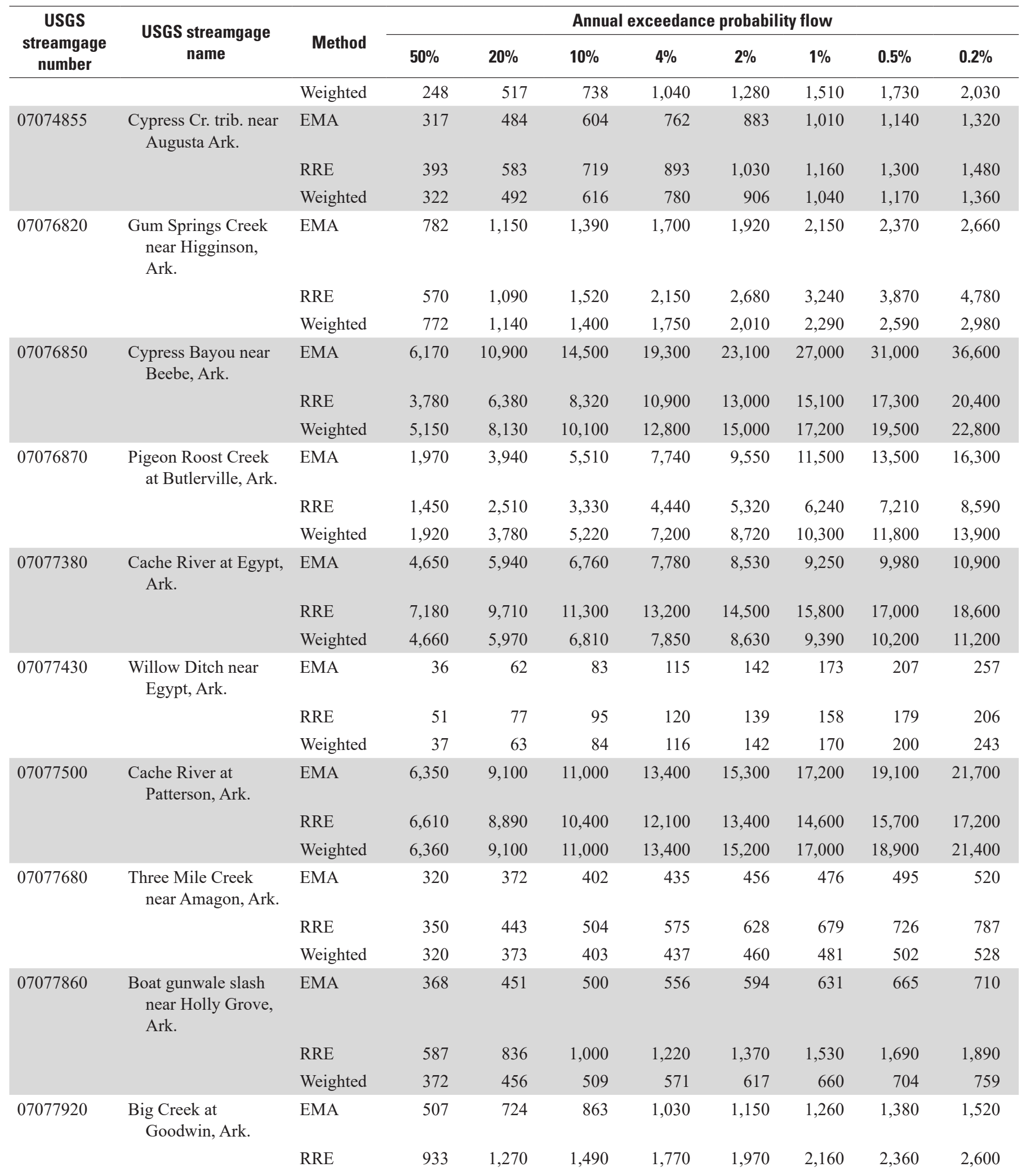


Table 3. Annual exceedance probability flows for 58 U.S. Geological Survey streamgages used in regional regression analysis based on data through the 2017 water year.-Continued

[Flows are in cubic feet per second. USGS, U.S. Geological Survey; \%, percent; Miss., Mississippi; Mo., Missouri; La., Louisiana; Ark., Arkansas; no., number; trib., tributary; St., State; Hw, highway; nr, near; Rs, research; Pd, pond; Byu, Bayou; COE, U.S. Army Corps of Engineers; EMA, Expected Moments Algorithm; RRE, regional regression equation; weighted, weighted estimate computed using equation 2; @, at; \%, percent]

\begin{tabular}{|c|c|c|c|c|c|c|c|c|c|c|}
\hline \multirow{2}{*}{$\begin{array}{c}\text { USGS } \\
\text { streamgage } \\
\text { number }\end{array}$} & \multirow{2}{*}{$\begin{array}{l}\text { USGS streamgage } \\
\text { name }\end{array}$} & \multirow{2}{*}{ Method } & \multicolumn{8}{|c|}{ Annual exceedance probability flow } \\
\hline & & & $50 \%$ & $20 \%$ & $10 \%$ & $4 \%$ & $2 \%$ & $1 \%$ & $0.5 \%$ & $0.2 \%$ \\
\hline & & Weighted & 515 & 737 & 880 & 1,060 & 1,180 & 1,310 & 1,440 & 1,600 \\
\hline \multirow[t]{3}{*}{07077940} & $\begin{array}{l}\text { Spring Creek near } \\
\text { Aubrey, Ark. }\end{array}$ & EMA & 1,470 & 1,750 & 1,910 & 2,090 & 2,220 & 2,330 & 2,440 & 2,580 \\
\hline & & RRE & 1,570 & 2,290 & 2,770 & 3,390 & 3,840 & 4,280 & 4,720 & 5,320 \\
\hline & & Weighted & 1,470 & 1,750 & 1,920 & 2,120 & 2,250 & 2,380 & 2,510 & 2,660 \\
\hline \multirow[t]{3}{*}{07077950} & $\begin{array}{l}\text { Big Creek at Poplar } \\
\text { Grove }\end{array}$ & EMA & 3,250 & 4,580 & 5,430 & 6,460 & 7,180 & 7,890 & 8,570 & 9,460 \\
\hline & & RRE & 3,990 & 5,280 & 6,100 & 7,080 & 7,780 & 8,430 & 9,080 & 9,890 \\
\hline & & Weighted & 3,330 & 4,690 & 5,570 & 6,610 & 7,340 & 8,060 & 8,740 & 9,610 \\
\hline \multirow[t]{3}{*}{07078000} & $\begin{array}{l}\text { Lagrue Bayou near } \\
\text { Stuttgart, Ark. }\end{array}$ & EMA & 2,370 & 3,980 & 5,140 & 6,670 & 7,830 & 9,020 & 10,200 & 11,800 \\
\hline & & RRE & 2,840 & 3,950 & 4,690 & 5,580 & 6,240 & 6,870 & 7,500 & 8,320 \\
\hline & & Weighted & 2,420 & 3,980 & 5,070 & 6,470 & 7,490 & 8,490 & 9,460 & 10,700 \\
\hline \multirow[t]{3}{*}{07078170} & $\begin{array}{l}\text { Little Lagrue Bayou } \\
\text { trib near Dewitt, } \\
\text { Ark. }\end{array}$ & EMA & 184 & 214 & 231 & 251 & 264 & 276 & 288 & 302 \\
\hline & & RRE & 159 & 237 & 292 & 366 & 422 & 479 & 537 & 615 \\
\hline & & Weighted & 184 & 214 & 232 & 252 & 266 & 280 & 293 & 309 \\
\hline \multirow[t]{3}{*}{07078210} & $\begin{array}{l}\text { Tarleton Creek } \\
\text { Tributary at Ethel, } \\
\text { Ark. }\end{array}$ & EMA & 67 & 115 & 154 & 212 & 261 & 315 & 376 & 466 \\
\hline & & RRE & 84 & 137 & 177 & 232 & 276 & 322 & 370 & 437 \\
\hline & & Weighted & 68 & 118 & 157 & 215 & 264 & 317 & 374 & 457 \\
\hline \multirow[t]{3}{*}{07263860} & $\begin{array}{l}\text { Mile Branch near } \\
\text { Tomberlin, Ark. }\end{array}$ & EMA & 393 & 484 & 537 & 598 & 641 & 681 & 718 & 764 \\
\hline & & RRE & 385 & 583 & 723 & 906 & 1,040 & 1,180 & 1,320 & 1,520 \\
\hline & & Weighted & 392 & 486 & 541 & 609 & 659 & 708 & 757 & 819 \\
\hline \multirow[t]{3}{*}{07264100} & $\begin{array}{l}\text { White Oak Branch } \\
\text { near Lonoke, Ark. }\end{array}$ & EMA & 857 & 1,240 & 1,480 & 1,770 & 1,990 & 2,190 & 2,390 & 2,640 \\
\hline & & RRE & 603 & 902 & 1,110 & 1,380 & 1,580 & 1,790 & 2,000 & 2,280 \\
\hline & & Weighted & 844 & 1,220 & 1,450 & 1,740 & 1,950 & 2,150 & 2,340 & 2,590 \\
\hline \multirow[t]{3}{*}{07286047} & $\begin{array}{l}\text { Tippo Bayou trib at } \\
\text { Phillip, Miss. }\end{array}$ & EMA & 18 & 23 & 25 & 29 & 32 & 34 & 37 & 40 \\
\hline & & RRE & 19 & 24 & 28 & 32 & 34 & 37 & 40 & 44 \\
\hline & & Weighted & 18 & 23 & 26 & 29 & 32 & 34 & 37 & 40 \\
\hline \multirow[t]{3}{*}{07287165} & $\begin{array}{l}\text { Mosquito Lake trib } \\
\# 1 \text { at Itta Bena, } \\
\text { Miss. }\end{array}$ & EMA & 57 & 73 & 84 & 98 & 109 & 120 & 131 & 146 \\
\hline & & RRE & 34 & 45 & 52 & 61 & 68 & 75 & 81 & 90 \\
\hline & & Weighted & 56 & 72 & 82 & 95 & 104 & 114 & 124 & 137 \\
\hline
\end{tabular}


Table 3. Annual exceedance probability flows for 58 U.S. Geological Survey streamgages used in regional regression analysis based on data through the 2017 water year.-Continued

[Flows are in cubic feet per second. USGS, U.S. Geological Survey; \%, percent; Miss., Mississippi; Mo., Missouri; La., Louisiana; Ark., Arkansas; no., number; trib., tributary; St., State; Hw, highway; nr, near; Rs, research; Pd, pond; Byu, Bayou; COE, U.S. Army Corps of Engineers; EMA, Expected Moments Algorithm; RRE, regional regression equation; weighted, weighted estimate computed using equation 2; @, at; \%, percent]

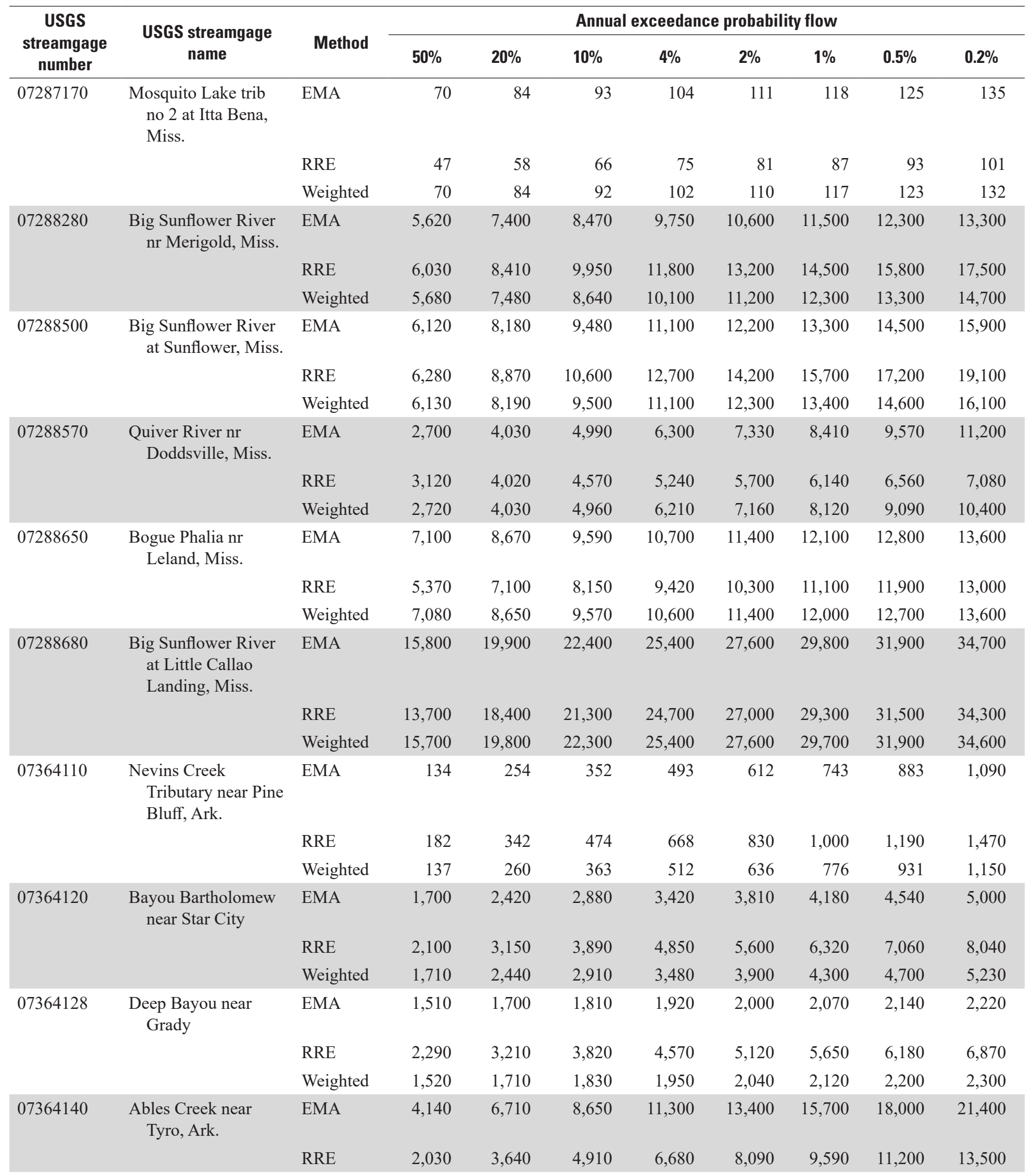


Table 3. Annual exceedance probability flows for 58 U.S. Geological Survey streamgages used in regional regression analysis based on data through the 2017 water year.-Continued

[Flows are in cubic feet per second. USGS, U.S. Geological Survey; \%, percent; Miss., Mississippi; Mo., Missouri; La., Louisiana; Ark., Arkansas; no., number; trib., tributary; St., State; Hw, highway; nr, near; Rs, research; Pd, pond; Byu, Bayou; COE, U.S. Army Corps of Engineers; EMA, Expected Moments Algorithm; RRE, regional regression equation; weighted, weighted estimate computed using equation 2; @, at; \%, percent]

\begin{tabular}{|c|c|c|c|c|c|c|c|c|c|c|}
\hline \multirow{2}{*}{$\begin{array}{c}\text { USGS } \\
\text { streamgage } \\
\text { number }\end{array}$} & \multirow{2}{*}{$\begin{array}{c}\text { USGS streamgage } \\
\text { name }\end{array}$} & \multirow{2}{*}{ Method } & \multicolumn{8}{|c|}{ Annual exceedance probability flow } \\
\hline & & & $50 \%$ & $20 \%$ & $10 \%$ & $4 \%$ & $2 \%$ & $1 \%$ & $0.5 \%$ & $0.2 \%$ \\
\hline & & Weighted & 3,750 & 6,050 & 7,680 & 9,950 & 11,900 & 13,700 & 15,600 & 18,500 \\
\hline \multirow[t]{3}{*}{07364150} & $\begin{array}{l}\text { Bayou Bartholomew } \\
\text { near McGehee, } \\
\text { Ark. }\end{array}$ & EMA & 3,330 & 4,550 & 5,300 & 6,180 & 6,810 & 7,410 & 8,000 & 8,730 \\
\hline & & RRE & 3,330 & 4,780 & 5,750 & 7,010 & 7,960 & 8,910 & 9,820 & 11,000 \\
\hline & & Weighted & 3,330 & 4,550 & 5,300 & 6,190 & 6,830 & 7,450 & 8,050 & 8,800 \\
\hline \multirow[t]{3}{*}{07364165} & $\begin{array}{l}\text { Upper Cutoff Creek } \\
\text { near Monticello, } \\
\text { Ark. }\end{array}$ & EMA & 897 & 1,630 & 2,240 & 3,130 & 3,900 & 4,740 & 5,680 & 7,050 \\
\hline & & RRE & 1,280 & 2,210 & 2,940 & 3,930 & 4,720 & 5,530 & 6,410 & 7,640 \\
\hline & & Weighted & 934 & 1,710 & 2,350 & 3,290 & 4,100 & 4,960 & 5,900 & 7,250 \\
\hline \multirow[t]{3}{*}{07364260} & $\begin{array}{l}\text { Hanks Creek near } \\
\text { Hamburg, Ark.. }\end{array}$ & EMA & 671 & 1,240 & 1,680 & 2,300 & 2,810 & 3,330 & 3,900 & 4,690 \\
\hline & & RRE & 1,150 & 1,870 & 2,390 & 3,090 & 3,630 & 4,190 & 4,760 & 5,560 \\
\hline & & Weighted & 719 & 1,310 & 1,790 & 2,450 & 2,990 & 3,540 & 4,140 & 4,960 \\
\hline \multirow[t]{3}{*}{07364300} & $\begin{array}{l}\text { Chemin-A-Haut } \\
\text { Bayou near } \\
\text { Beekman, La. }\end{array}$ & EMA & 5,130 & 11,500 & 17,300 & 26,200 & 34,000 & 43,000 & 52,800 & 67,600 \\
\hline & & RRE & 4,740 & 7,180 & 8,850 & 11,000 & 12,600 & 14,200 & 15,800 & 17,900 \\
\hline & & Weighted & 5,060 & 10,600 & 15,000 & 21,200 & 26,600 & 31,600 & 36,000 & 42,800 \\
\hline \multirow[t]{3}{*}{07364500} & $\begin{array}{l}\text { (COE) Bayou } \\
\text { Bartholomew near } \\
\text { Beekman, La. }\end{array}$ & EMA & 7,050 & 9,140 & 10,400 & 11,900 & 12,900 & 13,900 & 14,900 & 16,000 \\
\hline & & RRE & 5,510 & 7,600 & 8,990 & 10,700 & 12,000 & 13,200 & 14,500 & 15,900 \\
\hline & & Weighted & 7,030 & 9,120 & 10,400 & 11,900 & 12,900 & 13,900 & 14,800 & 16,000 \\
\hline \multirow[t]{3}{*}{07367658} & $\begin{array}{l}\text { Cypress Creek Canal } \\
\text { no. } 19 \text { trib nr } \\
\text { Dumas, Ark. }\end{array}$ & EMA & 156 & 207 & 240 & 281 & 310 & 340 & 368 & 406 \\
\hline & & RRE & 187 & 284 & 353 & 445 & 515 & 586 & 659 & 759 \\
\hline & & Weighted & 157 & 210 & 244 & 288 & 321 & 354 & 388 & 434 \\
\hline \multirow[t]{3}{*}{07368500} & $\begin{array}{l}\text { Big Colewa Byu nr } \\
\text { Oak Grove, La. }\end{array}$ & EMA & 1,060 & 1,400 & 1,600 & 1,850 & 2,030 & 2,200 & 2,360 & 2,570 \\
\hline & & RRE & 1,000 & 1,320 & 1,520 & 1,760 & 1,940 & 2,100 & 2,260 & 2,470 \\
\hline & & Weighted & 1,060 & 1,390 & 1,600 & 1,850 & 2,020 & 2,190 & 2,350 & 2,560 \\
\hline \multirow[t]{3}{*}{07369250} & $\begin{array}{l}\text { Turkey Cr trib at } \\
\text { Potato Rs Pd at } \\
\text { Chase, La. }\end{array}$ & EMA & 89 & 134 & 166 & 210 & 244 & 279 & 316 & 368 \\
\hline & & RRE & 89 & 133 & 165 & 207 & 240 & 272 & 306 & 352 \\
\hline & & Weighted & 89 & 134 & 166 & 209 & 243 & 278 & 314 & 363 \\
\hline \multirow[t]{3}{*}{07386000} & $\begin{array}{l}\text { Byu Carencro nr } \\
\text { Sunset La. }\end{array}$ & EMA & 2,360 & 3,240 & 3,820 & 4,530 & 5,060 & 5,580 & 6,110 & 6,790 \\
\hline & & RRE & 1,730 & 2,460 & 2,940 & 3,550 & 3,980 & 4,410 & 4,830 & 5,400 \\
\hline & & Weighted & 2,330 & 3,200 & 3,760 & 4,450 & 4,960 & 5,460 & 5,950 & 6,600 \\
\hline
\end{tabular}


Table 3. Annual exceedance probability flows for 58 U.S. Geological Survey streamgages used in regional regression analysis based on data through the 2017 water year.-Continued

[Flows are in cubic feet per second. USGS, U.S. Geological Survey; \%, percent; Miss., Mississippi; Mo., Missouri; La., Louisiana; Ark., Arkansas; no., number; trib., tributary; St., State; Hw, highway; nr, near; Rs, research; Pd, pond; Byu, Bayou; COE, U.S. Army Corps of Engineers; EMA, Expected Moments Algorithm; RRE, regional regression equation; weighted, weighted estimate computed using equation 2; @, at; \%, percent]

\begin{tabular}{|c|c|c|c|c|c|c|c|c|c|c|}
\hline \multirow{2}{*}{$\begin{array}{c}\text { USGS } \\
\text { streamgage } \\
\text { number }\end{array}$} & \multirow{2}{*}{$\begin{array}{c}\text { USGS streamgage } \\
\text { name }\end{array}$} & \multirow{2}{*}{ Method } & \multicolumn{8}{|c|}{ Annual exceedance probability flow } \\
\hline & & & $50 \%$ & $20 \%$ & $10 \%$ & $4 \%$ & $2 \%$ & $1 \%$ & $0.5 \%$ & $0.2 \%$ \\
\hline \multirow[t]{3}{*}{07386500} & $\begin{array}{c}\text { Byu Bourbeau @ } \\
\text { Shuteston, La. }\end{array}$ & EMA & 1,160 & 1,620 & 1,910 & 2,270 & 2,530 & 2,790 & 3,040 & 3,370 \\
\hline & & RRE & 793 & 1,110 & 1,320 & 1,590 & 1,790 & 1,990 & 2,180 & 2,430 \\
\hline & & Weighted & 1,150 & 1,600 & 1,880 & 2,220 & 2,470 & 2,710 & 2,950 & 3,250 \\
\hline \multirow{2}{*}{0728875070} & & RRE & 977 & 1,230 & 1,390 & 1,590 & 1,730 & 1,870 & 2,000 & 2,150 \\
\hline & & Weighted & 503 & 637 & 723 & 826 & 900 & 971 & 1,040 & 1,130 \\
\hline
\end{tabular}

A separate GLS analysis was conducted with drainage area as the only explanatory variable to produce the exponents of drainage area to be used in equation 3 . The exponent $(b)$ values are $0.572,0.564,0.559,0.553,0.549,0.546,0.543$, and 0.537 and should be used to transfer AEPs of $0.5,0.2,0.1$, $0.04,0.02,0.01,0.005$, and 0.002 , respectively.

The method just presented, however, does not weight the area-weighted flows at the ungaged locations with the flows computed using the regression equations. The AEP flows from the streamgage can be transferred and weighted with flows computed with the regression equations for the ungaged location using the following equation:

$$
Q_{P(u) w}=\left(\frac{2|\Delta A|}{A_{g}}\right) Q_{P(u) r}+\left(1-\frac{2|\Delta A|}{A_{g}}\right) Q_{P(u)},
$$

where

$$
\begin{aligned}
& Q_{P(u) w} \quad \text { is the weighted flow estimate at the ungaged } \\
& \text { location, in cubic feet per second; } \\
& |\triangle A| \quad \text { is the absolute difference in drainage areas } \\
& \text { between the ungaged location and the } \\
& \text { streamgage, in square miles; } \\
& A_{g} \quad \text { is the drainage area at the streamgage, in } \\
& \text { square miles; } \\
& Q_{P(u) r} \quad \text { is the flow estimate at the ungaged location } \\
& \text { for the selected AEP, computed using the } \\
& \text { regression equations, in cubic feet per } \\
& \text { second; and } \\
& Q_{P(u)} \quad \text { is the area-weighted estimate of flood flow, } \\
& \text { corresponding to the selected } P \text {-percent } \\
& \text { AEP, at the ungaged location, } u \text {, in cubic } \\
& \text { feet per second computed using equation } 3 \text {. }
\end{aligned}
$$

If the drainage area at an ungaged location differs by more than \pm 50 percent from that of the selected streamgage, the regression equations should be used to estimate AEP flows.
If an ungaged location is between two streamgages on the same stream, the streamgage with the drainage area nearest in size to that at the ungaged location and the longest period of record should be used to compute area-weighted estimates of AEP flows (Sauer, 1974).

\section{Locations on Ungaged Streams}

For locations on ungaged streams, the drainage area, slope, and basin shape ratio should be determined using StreamStats (USGS, 2017a). StreamStats delineates the drainage basin for the selected location, computes basin characteristics, and estimates flows for a range of AEPs. The standard error of prediction (SEP) is a measure of the accuracy of AEP flow estimates computed using the regression equations. The equations also apply to ungaged locations on gaged streams that are outside the range of 0.5 to 1.5 times the drainage area of the streamgage.

\section{Accuracy and Limitations of Regression Equations}

The regression equations are applicable at locations on streams that have basin characteristics within the range of those used to develop the equations. The methods described in this report do not apply to locations on streams that are substantially affected by regulation from upstream impoundments or other man-made structures. The regression equations are not applicable at locations on streams where more than 10 percent of the drainage area of the basin upstream of the location of interest is covered by impervious surfaces. The accuracy of the regression equations is not known for locations that have basin characteristics outside the following ranges used to develop 
the equations: drainage areas from 0.03 to $2,370 \mathrm{mi}^{2}$; channel slopes from 0.36 to 31.74 feet per mile; and basin shape ratios from 1.24 to 75.97 . The equations are valid for the MAP region in the States of Mississippi, Arkansas, Louisiana, and Missouri represented by streamgages used in the study (fig. 1; table 1).

The accuracy of a flood-frequency estimate traditionally has been expressed in two ways - as the mean standard error of the model or as the mean SEP. The mean standard error of the model is a measure of how well the regression model fits the streamgage data and represents the standard deviation of the differences between streamgage data and predictions from the regression equation. The SEP is a measure of how well the regression model estimates AEP flows for ungaged basins. The SEP is the square root of the mean square error of prediction. The mean square error of prediction is the sum of two components - the MSE resulting from the model and the sampling MSE resulting from estimating the model parameters from samples of the population. The MSE range (43-57 percent) and the SEP range (45-61 percent) for the GLS regression were within acceptable limits for AEP analysis (England and others, 2019).

\section{Summary and Conclusions}

Flood-frequency estimates for rural Mississippi Alluvial Plain streams in Mississippi were last updated in 1985; since that time, estimation techniques have improved, and additional annual peak streamflow data are available to improve the accuracy of such estimates. Thus, the U.S. Geological Survey, in cooperation with the Mississippi Department of Transportation, performed flood-frequency analyses to estimate annual exceedance probability (AEP) flows at streamgages and related the AEP flows to selected basin characteristics to develop a suite of generalized least-squares regression equations to estimate AEPs at ungaged locations in the Mississippi Alluvial Plain. Many basin characteristics were analyzed, but drainage area, slope, and a basin shape ratio yielded the best model and were used as explanatory variables in the regression equations. Standard error of prediction of the generalized least-squares models ranged from 45 to 61 percent. Pseudo- $\mathrm{R}^{2}$ of the models ranged from 90 to 94 percent. Standard model error ranged from 43 to 57 percent.

Floods have the potential to create devastating impacts to the economy, infrastructure, and the landscape. Keeping both the flood-frequency analyses at streamgages and the regression equations used to compute flood-frequency at ungaged locations updated on a publicly accessible web interface such as StreamStats (https://water.usgs.gov/osw/streamstats/) provides water-resource managers with critical information for floodresponse planning. By broadening the regional approach from parts of States to larger regions that cross State lines, floodfrequency estimates have the potential to be more accurate than previously possible and are applicable to a larger study area. Lastly, providing the tools to delineate drainage basins, compute basin characteristics, and compute AEP flows on StreamStats allows a user to select a site of interest and obtain flood information for the site at any time.

\section{References Cited}

Cohn, T.A., England, J.F., Berenbrock, C.E., Mason, R.R., Stedinger, J.R., and Lamontagne, J.R., 2013, A generalized Grubbs-Beck test statistic for detecting multiple potentially influential low outliers in flood series: Water Resources Research, v. 49, no. 8, p. 5047-5058, accessed June 12, 2020, at https://doi.org/10.1002/wrcr.20392.

Cohn, T.A., Lane, W.L., and Baier, W.G., 1997, An algorithm for computing moments-based flood quantile estimates when historical flood information is available: Water Resources Research, v. 33, no. 9, p. 2089-2096, accessed June 12, 2020, at https://doi.org/10.1029/97WR01640.

Colson, B.E., and Hudson, J.W., 1976, Flood frequency of Mississippi streams: Mississippi State Highway Department, RO-76-014-PR, 34 p.

Eng, K., Chen, Y.Y., and Kiang, J.E., 2009, User's guide to the weighted-multiple-linear regression program (WREG version 1.0): U.S. Geological Survey Techniques and Methods, book 4, chap. A8, 21 p. [Also available at https://pubs .usgs.gov/tm/tm $4 \mathrm{a} 8 /$.

England, J.F., Jr., Cohn, T.A., Faber, B.A., Stedinger, J.R., Thomas, W.O., Jr., Veilleux, A.G., Kiang, J.E., and Mason, R.R., Jr., 2019, Guidelines for determining flood flow frequency_Bulletin 17C (ver. 1.1, May 2019): U.S. Geological Survey Techniques and Methods, book 4, chap. B5, 148 p., accessed June 13, 2020, at https://doi.org/ $10.3133 / \mathrm{tm} 4 \mathrm{~B} 5$.

Griffis, V.W., and Stedinger, J.R., 2007, Log-Pearson type 3 distribution and its application in flood frequency analysis. II-Parameter estimation methods: Journal of Hydrologic Engineering, v. 12, no. 5, p. 492-500, accessed June 12, 2020, at https://doi.org/10.1061/(ASCE)10840699(2007)12:5(492).

Interagency Advisory Committee on Water Data, 1982, Guidelines for determining flood-flow frequency: Interagency Advisory Committee on Water Data Bulletin 17B, 183 p.

Landers, M.N., 1985, Floodflow frequency of streams in the alluvial plain of the lower Mississippi River in Mississippi, Arkansas, and Louisiana: U.S. Geological Survey Water Resources Investigations Report 85-4150, 21 p.

Parrett, C., Veilleux, A., Stedinger, J.R., Barth, N.A., Knifong, D.L., and Ferris, J.C., 2011, Regional skew for California, and flood frequency for selected sites in the SacramentoSan Joaquin River Basin, based on data through water year 2006: U.S. Geological Survey Scientific Investigations Report 2010-5260, 94 p., accessed March 25, 2020, at https://doi.org/10.3133/sir20105260. 
Ries, K.G., III, and Dillow, J.J.A., 2006, Magnitude and frequency of floods on nontidal streams in Delaware: U.S. Geological Survey Scientific Investigations Report 2006-5146, 59 p., accessed March 25, 2020, at https://doi.org/10.3133/sir20065146.

Sauer, V.B., 1974, Flood characteristics of Oklahoma streams, techniques for calculating magnitude and frequency of floods in Oklahoma, with compilations of flood data through 1971: U.S. Geological Survey Water-Resources Investigations Report 73-52, 307 p.

Southard, R.E., and Veilleux, A.G., 2014, Methods for estimating annual exceedance-probability discharges and largest recorded floods for unregulated streams in rural Missouri: U.S. Geological Survey Scientific Investigations Report 2014-5165, 39 p., accessed March 25, 2020, at https://doi.org/10.3133/sir20145165.

U.S. Climate Data, 2020, Climate data for Greenwood, Mississippi: U.S. Climate Data web page, accessed April 7, 2020, at https://www.usclimatedata.com/climate/ greenwood/mississippi/united-states/usms0142.

U.S. Geological Survey, 2013, WREG, weighted-multiplelinear regression program: U.S. Geological Survey web page, accessed June 1, 2014, at https://water.usgs.gov/ software/WREG/.
U.S. Geological Survey, 2014, PeakFQ: U.S. Geological Survey web page, accessed July 3, 2013, at https://water .usgs.gov/software/PeakFQ/.

U.S. Geological Survey, 2017a, Welcome to StreamStatsStreamflow statistics and spatial analysis tools for water resources: U.S. Geological Survey online application, accessed March 25, 2020, at https://water.usgs.gov/osw/ streamstats/.

U.S. Geological Survey, 2017b, USGS water data for the Nation: U.S. Geological Survey National Water Information System database, accessed March 25, 2020, at https://doi.org/10.5066/F7P55KJN. [Peak-flow data directly accessible at https://nwis.waterdata.usgs.gov/usa/ nwis/peak.]

Wagner, D.M., Krieger, J.D., and Veilleux, A.G., 2016, Methods for estimating annual exceedance probability discharges for streams in Arkansas, based on data through water year 2013: U.S. Geological Survey Scientific Investigations Report 2016-5081, 136 p., accessed July 30, 2014, at https://doi.org/10.3133/sir20165081.

Wilson, K.V., and Trotter, I.L., Jr., 1961, Floods in Mississippi, magnitude and frequency: U.S. Geological Survey Open File Report, 326 p. 

For more information about this publication, contact Director, Lower Mississippi-Gulf Water Science Center U.S. Geological Survey

640 Grassmere Park, Suite 100

Nashville, TN 37211

For additional information, visit

https://www.usgs.gov/centers/lmg-water/

Publishing support provided by

Lafayette Publishing Service Center 
